Research Paper

\title{
Prediction of Interpersonal Cognitive Distortions based on the Worship of Celebrities and Parasocial Interaction with them
}

\author{
Reza Shabahang*1, Farzin Bagheri Sheykhangafshe $^{2}$, Adeleh Yousefi Siakoucheh ${ }^{2}$ \\ 1. M.A. Student in General Psychology, Faculty of Psychology and Educational Sciences, University of Tehran, Tehran, Iran \\ 2. M.A. Student in General Psychology, Faculty of Literature and Humanities, University of Guilan, Rasht, Iran
}

Received: November 15, 2018

Accepted: March 8, 2019

\begin{abstract}
Background and Purpose: The fascination with celebrities and the parasocial interaction with them can be effective in interpersonal cognitive distortions. In this regard, the present study aimed to predict interpersonal cognitive distortions based on the worship of celebrities and parasocial interaction with them.

Method: The present research is descriptive and correlational. The statistical population of the study consisted of high school students in the first district of Rasht city in the academic year 20182019. The sample consisted of 200 male and female students of the eighth and ninth grades who were selected by convenience sampling method. The scales of interpersonal cognitive distortions (Hamamci \& Büyüköztürk, 2004), celebrity attitude (McCutcheon, Lange \& Houran, 2002), and celebrity parasocial interaction (Bocarnea \& Brown, 2007) were used to gather the data. Multiple stepwise regression analysis was used to analyze the data.

Results: The results showed that the parasocial interaction $(\beta=0.27)$ at the significance level of 0.05 and celebrity worship $(\beta=0.30)$ and its subscales including entertainment-social $(\beta=0.13)$, intense-personal $(\beta=0.14)$, and borderline-pathological $(\beta=0.65)$ at the significant level of 0.01 , were able to predict interpersonal cognitive distortions in adolescents

Conclusion: The results showed the possibility of predicting interpersonal cognitive distortions based on the worship of celebrities and parasocial interaction with them. The implications of the results are discussed in the paper.
\end{abstract}

Keywords: Interpersonal cognitive distortions, celebrity worship, parasocial interaction

Citation: Shabahang R, Bagheri Sheykhangafshe F, Yousefi Siakoucheh A. Prediction of interpersonal cognitive distortions based on the worship of celebrities and parasocial interaction with them. Quarterly Journal of Child Mental Health. 2019; 6(1): 163-175.

*Corresponding author: Reza Shabahang, M.A. Student in General Psychology, Faculty of Psychology and Educational Sciences, University of Tehran, Tehran, Iran.

Email: Reza.shabahang@ut.ac.ir

Tel: (+98) 9022225857 


\title{
ييشبينى تحريفات شناختى بينفردى بر اساس يرستش افراد مشهور و تعامل فرا اجتماعى با آنان
}

\author{
رضا شباهنكَ"'، فرزين باقرى شيخانكفشه '، عادله يوسفى سياكوجه r \\ ا. دانشجوى كارشناسى ارشد روانشناسى عمومى، دانشكده روانشناسى و علوم تربيتى، دانشكاه تهران، ايران

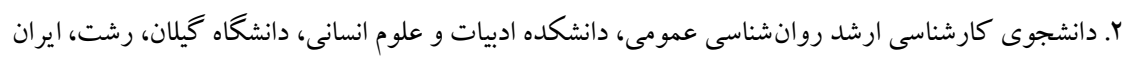

Q تاريخ بذيرش: PV/IY/IV

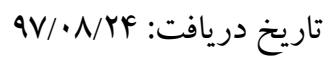

\section{جـكيده}

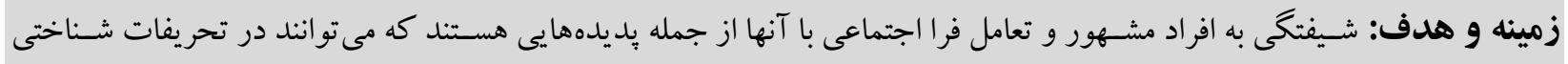

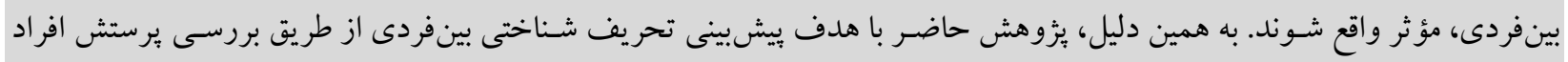
مشهور و تعامل فرا اجتماعى با آنها است. روش: يزو هش حاضر توصيفى و از نوع همبستخى است. جامعه آمارى يثروش شامل دانش آموزان مدارس متوسطه دوره اول ناحيه دو

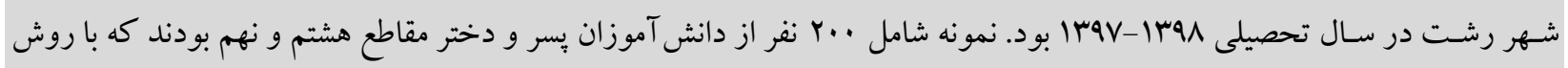

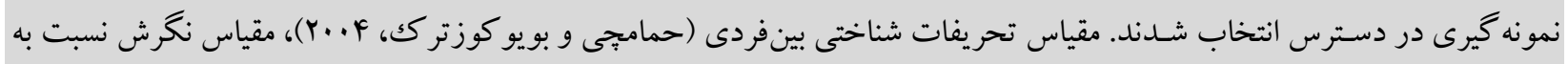

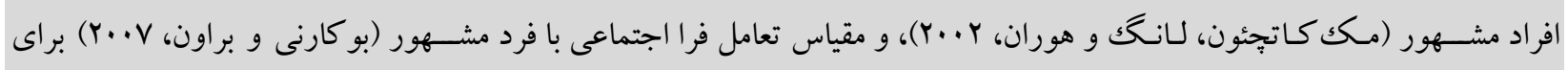

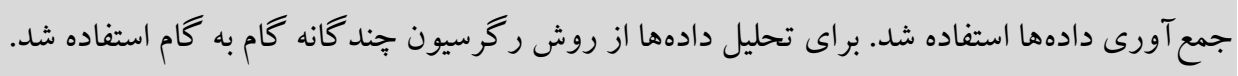

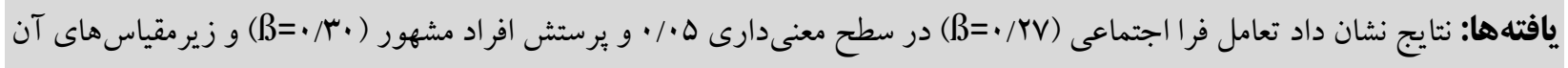

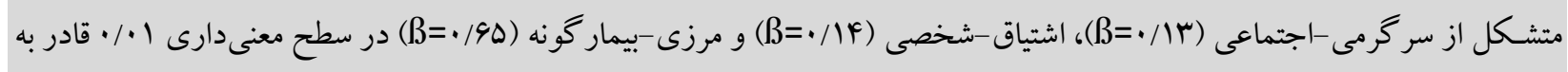
بيش بينى تحريفات شناختى بين فردى هستند.

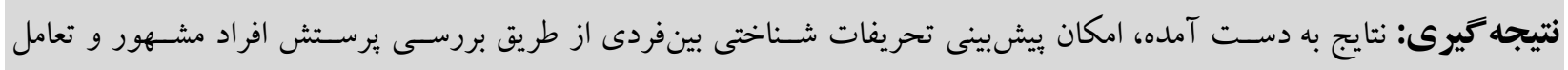

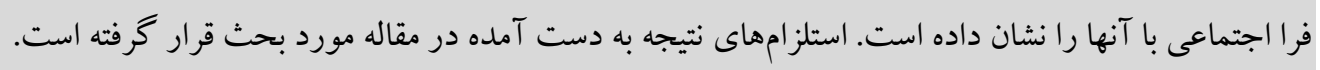
كليدوازهها؛ تحريفات شناختى بينفردى، يرستش افراد مشهور، تعامل فرا اجتماعى

*نويسنده مسئول: رضا شباهنك، دانشجوى كارشناسى ارشد روانشناسى عمومى، دانشكده روانشناسى و علوم تربيتى، دانشكاه تهران، ايران.

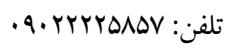

ايميل:Reza.shabahang@ut.ac.ir 
طرفدارانشان، به همر اه داشته است (V). شيفتخى افراطى نسبت به اشـخاص مشـهور مورد علاقه به عنوان برستش افر اد مشهورَّ

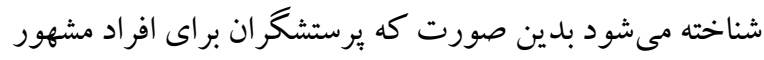
مورد علـاقهشــان احترام بسـيـارى قائل هســتند و كمبو دها و

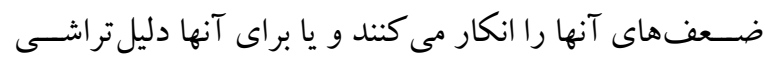

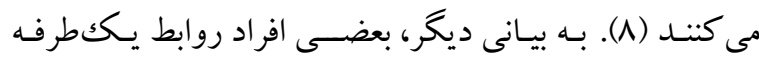

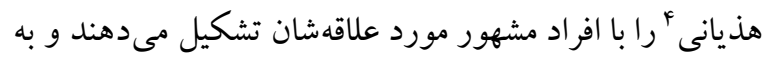

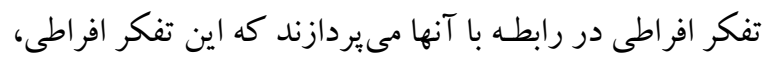
بر سـتش افراد مشهور ناميده مى شود (9). در همين رابطه، مكك

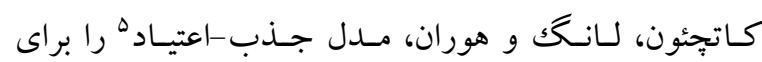
توصسيف، شـناسـايى، ارزيابى، و تبيين برسـش افر اد مشـهور

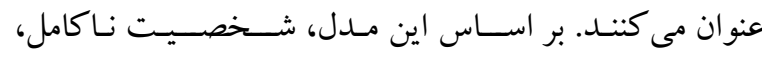

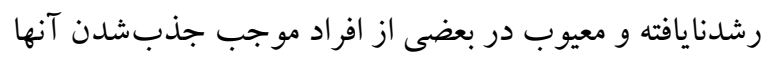
به اشـخاص مشهور به منظور تشكيل و تكميل هويت مى شود

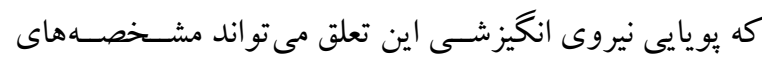

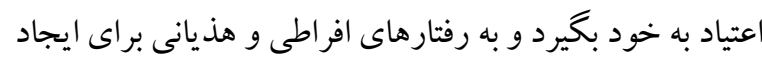
و حفظ روابط با افراد مشهور منجر شود (V).

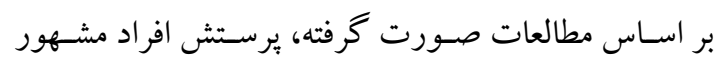

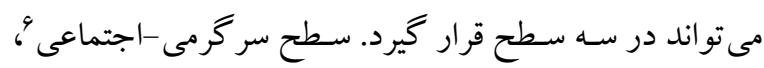

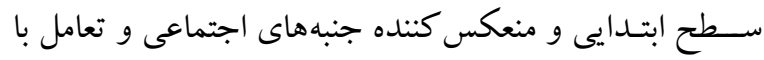

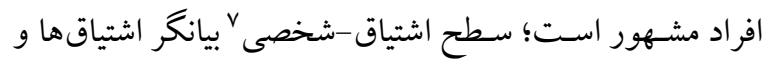

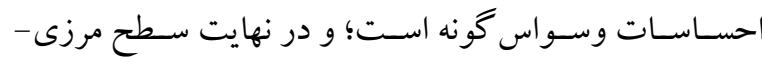

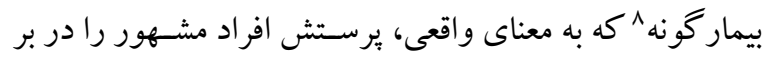

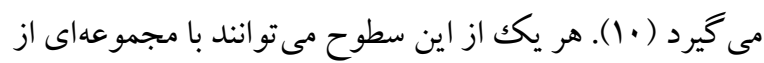

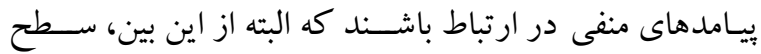

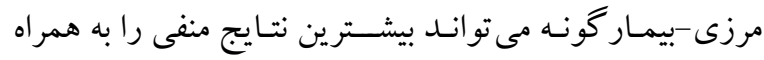

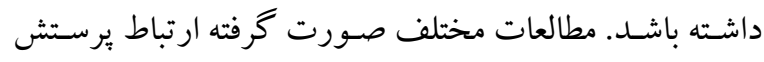

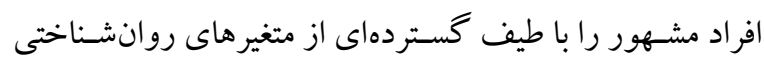
همجون سـلامت روان (11)، بهزيسـتى روانشـناختى (r) و (I)

5. Absorption-addiction

6. Entertainment-social

7. Intense-personal

8. Borderline-pathological

\section{مقلممه}

بر طبق روى آورد شــــاختى رفتـارى، بـاورهـاى غيرمنطقى و تحريفـات شـــــاختى مى تواننـد نقشــى مهم در ايجـاد و ادامه رفتارهاى ناكار آمد و مشـكلات روانشـناختى ايفا كنتد كه در

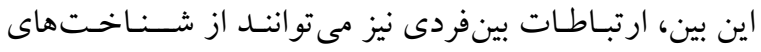
غيرمنطقى تأثير بيذيرند. در واقع تحريفات شـناختى بينفردى' به عنوان تحريفهاى شـناختى در ارتباطات و تعاملات افراد با يكديگر تلقى مى شوند كه مىتوانند بيامدهاى منفى بسيارى را در سطوح مختلف به همراه داشته باشند ( (1). نوجوانان با توجه بـه مشــخصــههايى كه دارند از جمله كروههايى هســتند كه تحريفات شـناختى بينفردى مى توانند در آنها بر جسـته باشـند. نوجوانى دوره انتقالى ب اسـت كه در آن مجموعهاى از تغييرات مختلف رخ مى دهد (Y). در اين دوره، ايجاد و حفظ ارتباطات بين فردى از اهميـت بســيارى برخوردار اســت و افراد در اين ســنين با مســـله مهمى به نام تشـكيل روابط بين فردى نزديكك

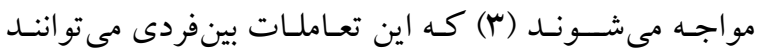
تنش هاى بسيارى را به همر اه داشته باشند (Y). با توجه به كسترش فرهنگ افراد مشـهور و اهميت آن در جوامع امروزى، شـيفتخى نســبت به افراد مشــهور و تعامل فرا اجتماعى با آنها از جمله موضــوعاتى هســتند كه مي توانند در ايجـاد تحريفـات شـــــاختى بين فردى در نوجوانـان موثر واقع شوند. در دنياى امروز، فرهنگ افراد مشهور به سرعت در حال كسترش اسـت و موضسوعات مرتبط با افراد مشهور به مباحثى بسـيار مهم در رسـانهاى خبرى قرن ال تبديل شـدهاند (F) و سـتار كان فيلمها، سـتار كان ورزشـى، دانشـمندان، مدلهاى قهرمانانه، و رهبران ســياسـى به افرادى قابل برســش تبديل شــدهاند (ه). اين يديده توجه بسـيارى از دانشــمندان علوم اجتماعى را به خود جلب كرده اسـت (4) و نكر انى بسيارى از يثزوهشخران را درباره نقش شيفتكى به افراد مشهور در زندكى

1. Interpersonal cognitive distortions

2. Transitional period

3. Celebrity worship

4. Delusional one-sided relationships 
مشكلات بين فردى (•Y)، تنهايى و خجالت (YI) نشان مى (Y)

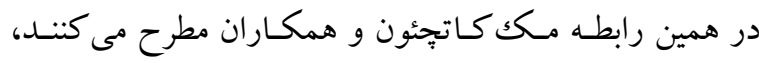

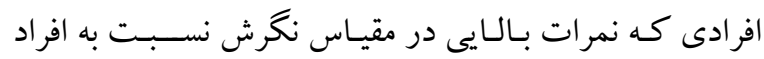

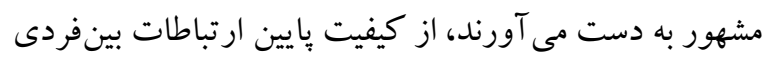
برخوردار هسـتند و تعاملات مشـكلدار و اضـطر ابى دارند. به

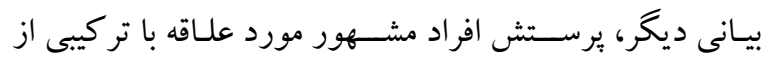

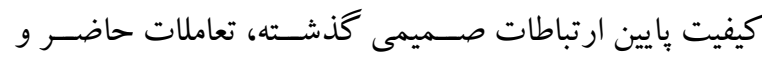

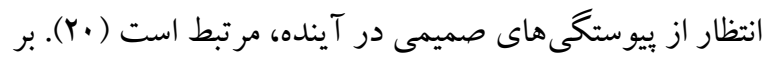
همين اســاس، تحريف شــناختى بينفردى به عنوان يديدهاى

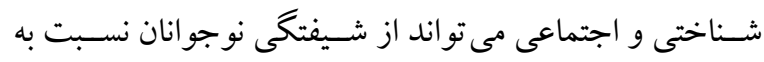
افراد مشهور مورد علاقهشان تأثير بيذيرد و ارتباط برستش وست افراد مشهور را با تحريفات شناختى بين فردى متصور بود.

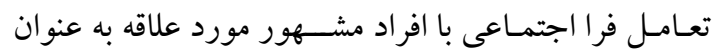

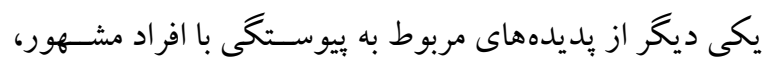

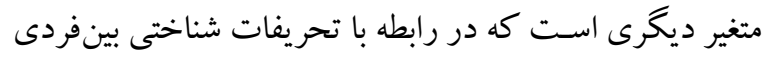
مى توان در نظر داشت. بديده فرا اجتماعى به منظور توصيف و

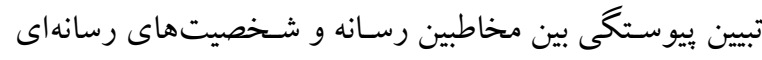

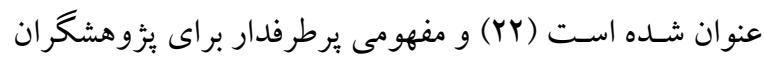
حوزه رسـانه اسـت (Yr). در واقع، ايجاد توهم ارتباط جهره به

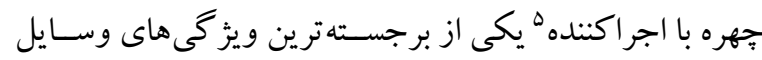
ارتبـاط جمعى اســت. اين ارتبـاط جهره به جهره ظاهرى به بين

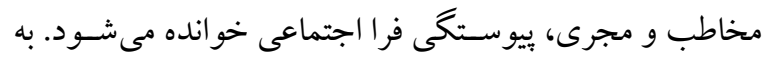

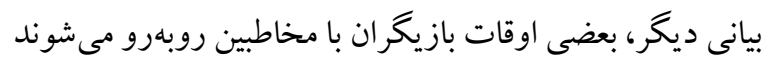

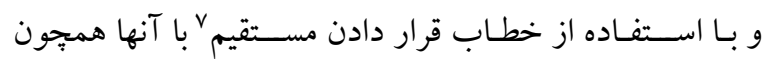
كفتخو يى شـخصى و خصسوصسى، ارتباط برقرار مى كنند كه

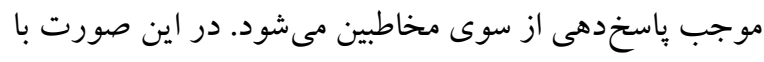

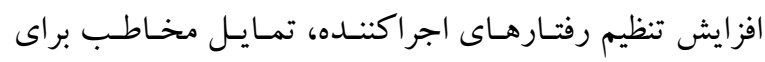

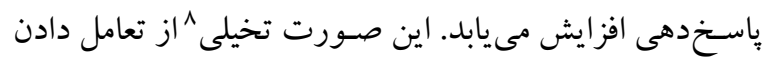
و گرفتن، به عنوان تعامل و ارتباط فر ا اجتماعى شناخته مى شود إنى

5. Performer

6. Seeming face to face relationship

7. Direct address

8. Simulacrum

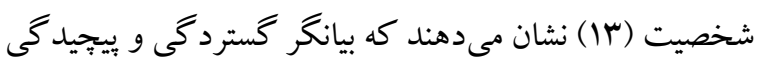
بديده برستش افراد مشهور و اهميت بررسى و تبئين آن هستند. ئزوهش هاى انجام شـده درباره برسـتش افراد مشهور نشان مى دهند كه ابعاد و مؤلفه هاى شـناختى، نقشى مهم در شيفتكى

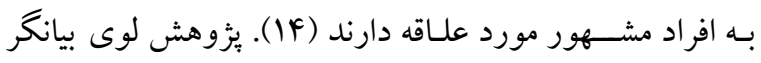
همبستخكى منفى تحصيلات با برستش افراد مشهور است (ه). فوجى، احمد و تاكشـيتا با بررسـى دو بيمار با مشــصـههاى اروتومانيا' به عنوان اختلالى بسيار شبيه به برستش افراد مشهور، عنوان مى كنــد كـه در نيمرخ عصــب روانشـــــاختى ب آنهـا نـارســايىهـايى وجود دارد و نقصهـايى را در آزمونهـاى دسـتهبندى كارت هاى ويسـكانسـين، هوش و كســلر، و ديخر آزمونهاى عصسبرووانشـناختى نشان مىدهند كه بيانكر وجود نقصسانهايى در حافظه فعال، انعطاف يذيرى شناختى، و توانيى ايجاد ارتباطات كلامى آنها اسـت (19). مكك كاتجئون، اش،

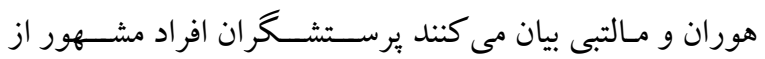
تو انايى هاى شناختى كمترى برخوردار هستند و نمرات كمترى در آزمونهاى شـناختى كسـب مى كنند (IV). هم:جنين مالتبى و همكـار ان اذعان مى كنتد، انعطاف يذيرى شـــاختى به عنوان يكك توانايى شناختى بر جسته با يرستش افراد مشهور همبستگى منفى دارد و نقص در انعطاف يذيرى شــاختى، ييشبينى كننده حيطه مرزى-بيمار گونه برستش افراد مشـهور است (به نقل از (If) منفى انعطاف يذيرى شـناختى را با دو بعد اشـتياق-شـخصسى و مرزى-بيمار گونه يرستش افراد مشـهور، گزارش كردند (1N). در واقع مى توان در نظر داشت كه نخرش افراطى نسبت به افراد مشهور و شيفتگى به آنها با ابعاد شناختى رابطه تنگًانگى دارند. همجينين نتايج مطالعات صــورت گرفته، ارتباط ســتايش

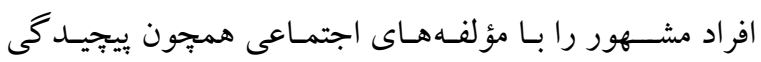

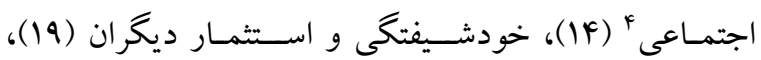

1. Erotomania

2. Neuropsychological profile

3. Maltby et al

4. Social complexity 
آنها در تبيين تحريفات شـناختى بين فردى، بسـيار حائز اهميت است. بر همين اساس هدف از يثوهش حاضر ياسخدهى به اين

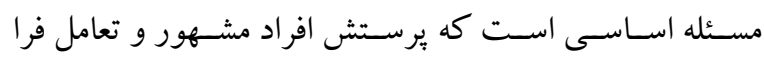

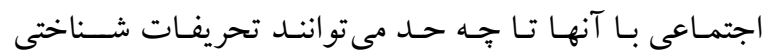
بين فردى را ييش بينى كنند.

روش الف) طرح :ثزوهش و شر كت كنند كان: طرح يثزوهش حاضر توصيفى و از نوع همبستخى است. جامعه آمارى بثزوهش شامل

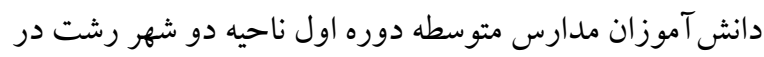

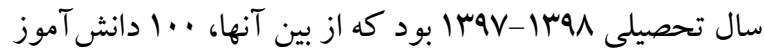
دختر و . .1 دانشآموز يسر مقاطع هشتم و نهم با روش نمونه گيرى در دسترس به عنوان نمونه مورد مطالعه انتخاب

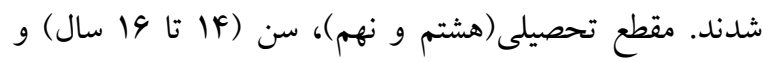

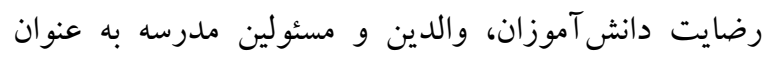
ملاككهاى ورود شر كت كنند گان در نظر گرفته شدند. همجِنين ملاككهاى خروج از يزٔوهش شامل وجود اختلالات جسمانى و روانى ناتوان كننده قابل مشاهده، عدم رضايت دانش آموزان،

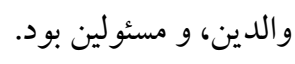

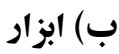

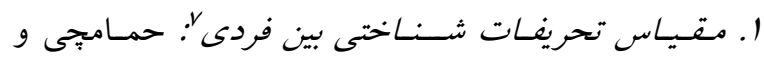

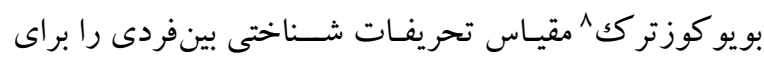
ارزيابى تفكرات نامعقول و تحريفهاى شناختى افرادى كه در ارتبـاط با ديخران هســتند، طراحى كردهاند. اين مقياس از 19

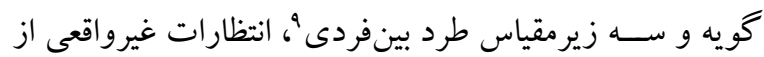

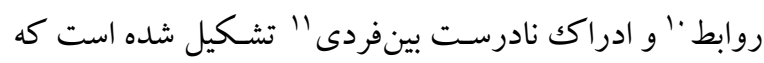

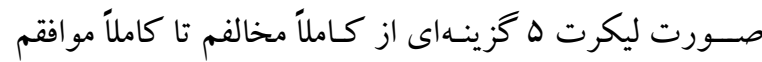
يـاســخ خدهى و نمرهدهى مى شـــود. نمرات بـالـاتر در مقيـاس

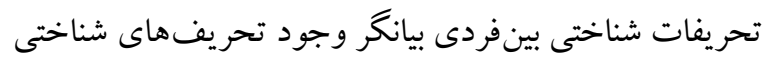

7. Interpersonal cognitive distortions scale

8. Hamamci \& Büyüköztürk

9. Interpersonal rejection

2. Unrealistic relationship expectation

11. Interpersonal misperception
كه مشخصه اصلى آن نبود رابطه متقابل مؤثر' است و تعامل به صسورت يككطرفه، غيرجدلى بَ، و قابل مهار توسـط اجراكننده است (YY). ئزو هشهاى انجامشده در مورد تعامل فرا اجتماعى تونى

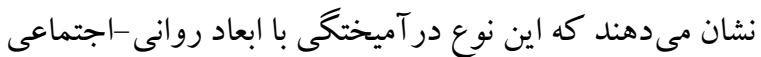

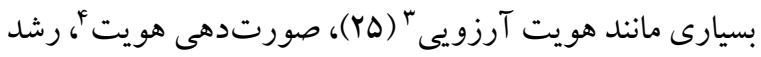

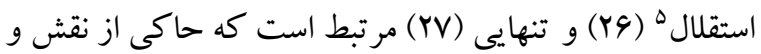
اهميت تعامل فرا اجتماعى با شـخصيتهاى رسانهاى است. در

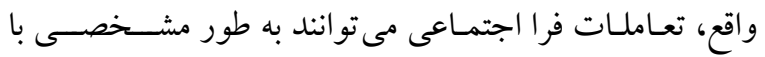

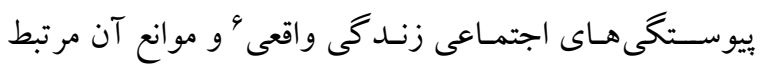

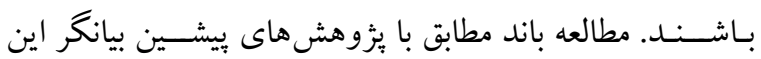
موضــوع اســت كـه ارتباطات فرا اجتماعى، مكمل ارتباطات

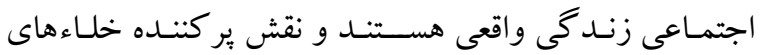

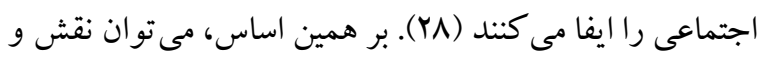

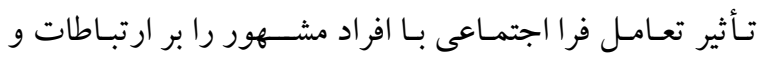
تحريفات شناختى بين فردى نوجوانان در نظر داشت. در واقع مى توان متصور بود، يرستش افراد مشهور و تعامل

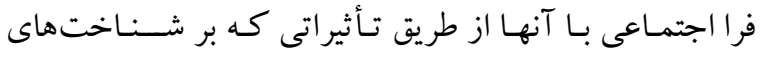

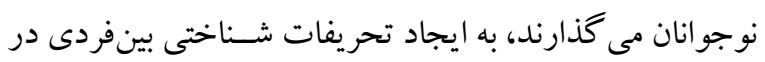

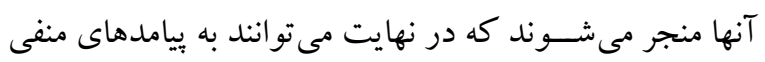

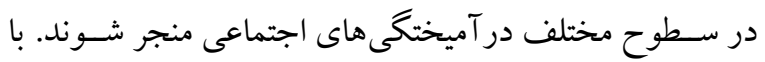
توجه به گسترش روزافزون دسترسى به وسايل ارتباط جمعى و

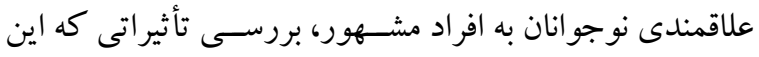

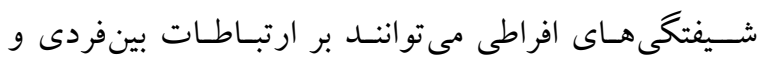

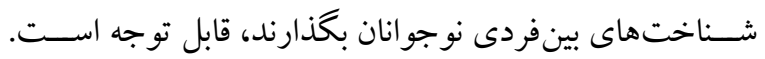
همجنين عـدم وجود مطـالعـاتى مشــخص در مورد ارتبـاط

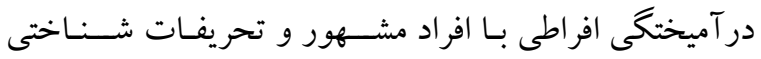

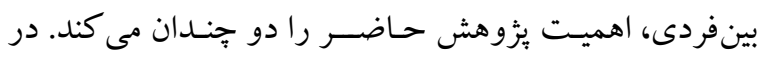
همين راستا نقش يرستش افراد مشهور و تعامل فرا اجتماعى با تيا تركي

1. Lack of effective reciprocity

2. Nondialectical

3. Wishful identification

4. Identity formation

5. Autonomy development

6. Real-life social bonds 
مرزى و يرسشنامه سبك هاى دفاعى) و روايى سازه (همبستخى

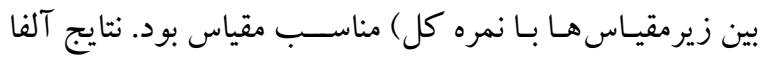

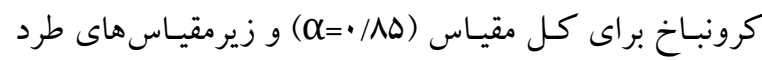

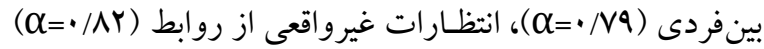
و ادراكك نادرست بينفردى با يكديخر ( همســانى درونى مطلوب مقياس تحريفات شــاختى بين فردى

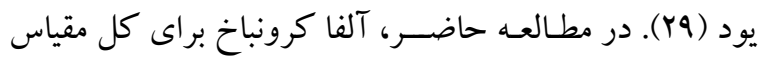

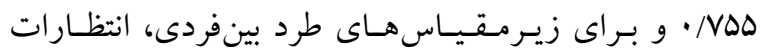

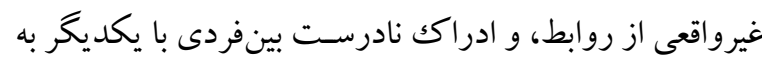
ترتيب 1941•، • • • • و 19010 • •بدست آمد.

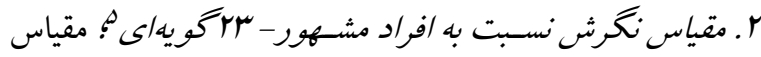

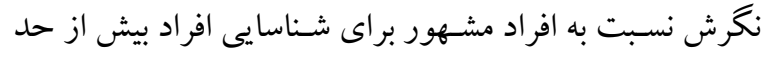
جذب شده يا معتاد \به افراد مشهور تهيه و طراحى شده است.

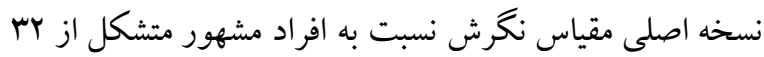

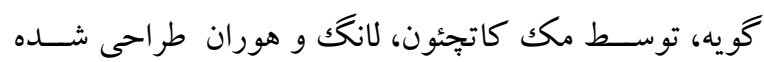

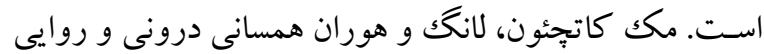

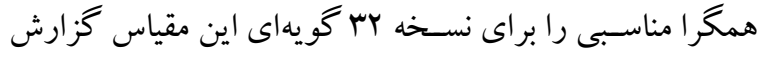

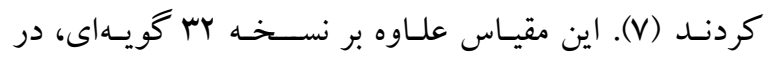

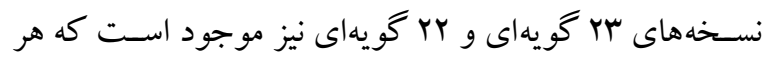
يكك از آنها، نكرش افراد ران انسـبت به اشـخاص مشـهور مورد علاقه شان ارزيابى مى كنند ( •r). نتايج به دست آمده، اعتيار و

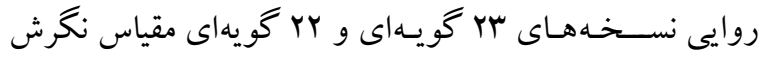
نسـبت به افراد مشـهور را نشـان مى دهند (سا). مقياس نغرش

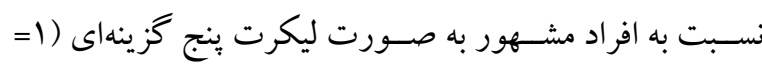

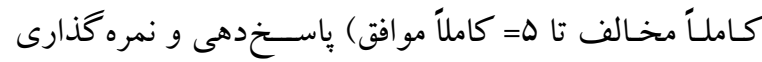
مىشـود (V). مالتبى و همكاران طى مطالعاتشان، سه زيرمقياس

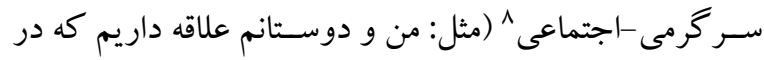

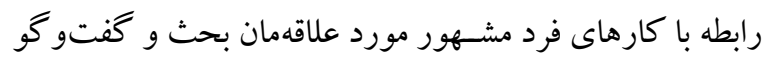

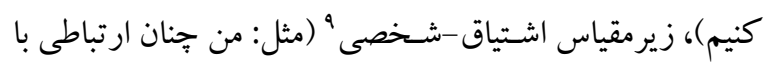

6. Absorbed

7. Addicted

8. Entertainment-social

9. Intense-personal
بيشـتر در وييوستـى هاى بينفردى است. نتايج مطالعه حمامجى

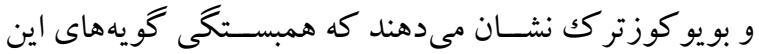

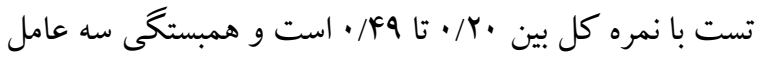
با يكديخر بين V•/ • و ه/ • اســت كه حاكى از ارتباط بايين

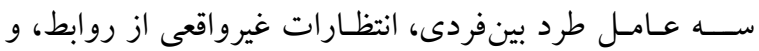
ادراك نادرست بين فردى با يكديخر و استقلال و تمايز عاملهـا

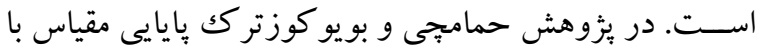
روش آلفا كرونباخ براى كل مقياس 9V/ •، زيرمقياس بين فردى

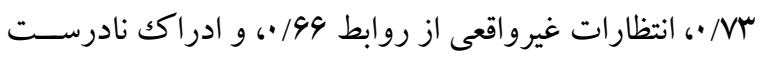

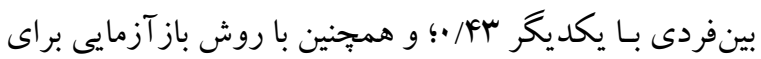

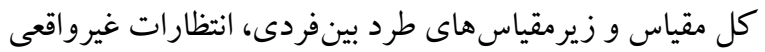
از روابط، و ادراكك نـادرسـت بين فردى بـا يكديخر به ترتيب

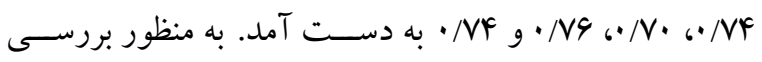
روايى مقيـاس، حمـامبجى و بويو كوزتركك بـه بررسـى ارتباط مقيـاس تحريفـات شــــاختى بين فردى بـا ابزارهـاى عقـايــــا

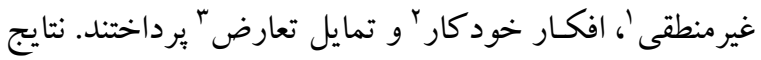

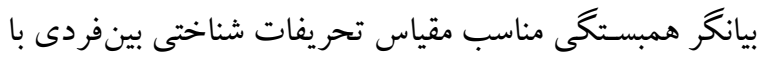

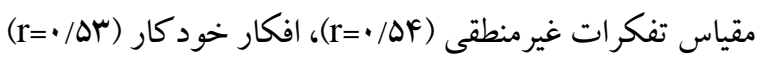
و تمايل تعارض (r=•/Dr) بودند. به منظور تهيه شـواهد بيشـتر براى روايى مناسب مقياس، از برسشنامه زندگى متاهلى استفاده

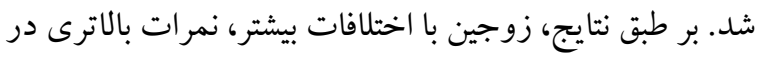
مقياس تحريفات شـناختى بين فردى كسـب مى كردند (1). در

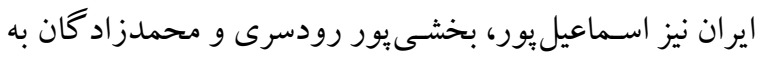
بررسى مشـخصـهاى روانسـنجى مقياس تحريفات شـناختى بين فردى برداختنـد. تحليـل عـاملى مقيـاس بـه روش تحليـل

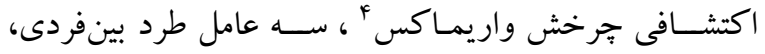
انتظارات غيرواقعى از روابط، و ادراكك نادرسـت بين فردى را استخراج كرد. همجينين نتايج بيانگر روايى همزمان (همبستخى ورانى مقياس تحريفات شـناختى بين فردى با مقياس صفات شخصيت

1. Irrational beliefs

2. Automatic thoughts

3. Conflict tendency

4. Varimax-rotated exploratory factor analysis

5. Celebrity worship attitude- 23 items 
فرا اجتمـاعى از طريق تلويزيون طراحى شـــدانـد، اين مقياس تعاملات فرالجتماعى فراتر از تلويزيون را هم در بر دارد. مقياس

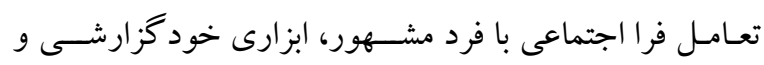

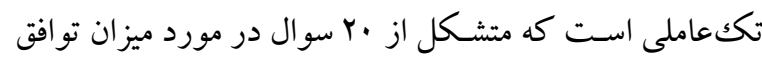
با جملات مربوط به تعامل فرالجتماعى با اشخاص مشهور است

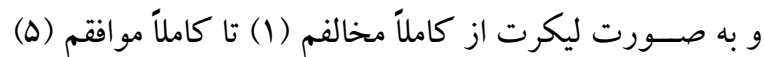
ياسـخ دهى و نمره گذارى مى شـود. مطالعات انجام شده، بايايى

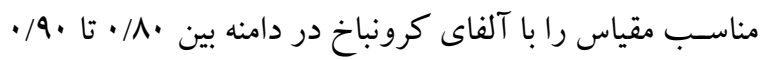

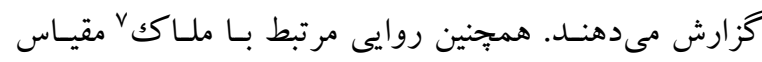
تعامل فرا اجتماعى با فرد مشــهور با توجه به كار آمدى ماش در

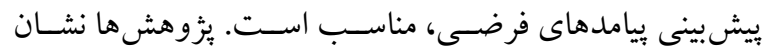

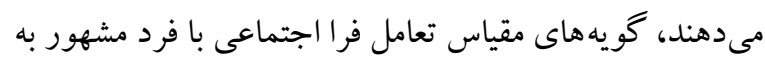

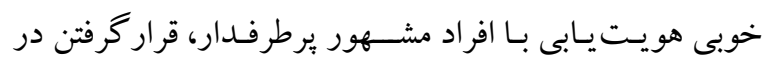
معرض شــخصـيتها، و اشــخاص در رســانههاى جمعى را ييشبينى مى كنند. روايى سـازه مقياس نيز با توجه به استنتاج از متغيرهاى غيرقابل مشـاهدهُ، رضـايتبخش اسـتـ در مجموع تحليل عاملى گويههاى مقياس نشان مىدهند كه مقياس ارتباط

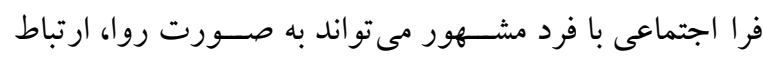

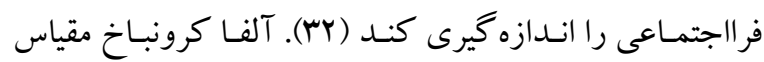

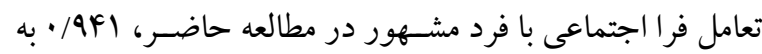
دست آمد كه اعتبار مناسب مقياس را نشان مىدهد إعد. ج) روش اجرا: بِ إز هماهنگگها و اخذ مجوز از ســازمان

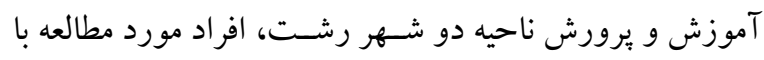

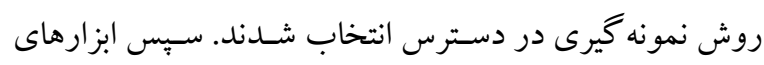

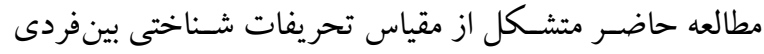
(1)، مقياس نكرش نسبت به افراد مشهور (V)، و مقياس تعامل فرا اجتمـاعى با فرد مشــهور (Tr) به آنها ارائه شــد. بهمنظور

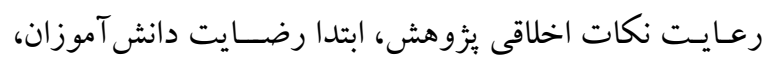
والـدينشــان، و مســؤين مـدرسـهـ جلـب شــد. همجنين به

\section{Cole \& Leets}

6. Auter \& Palmgreen

7. Criterion related validity

8. Unobserved variables
فرد مورد مشههور مورد علاقهام دارم كه در كلمات نمى گنجد) و زيـرمســــاس مـرزى-بيمـار گونـه' (مثـل: اكر من آنقــدر خوش شـانس باشم كه فرد مشهور مورد علاقهام را ملاقات كنم و او از من خيزى غيرقـانونى بخواهـــ، احتمـالـاً آن را انجـام خواهم داد) را براى مقياس نخرش نسبت به افر اد مشهور عنو أنوان مى كنند (11). در مطالعه حاضـر از نسـخه سب گويهاى مقياس

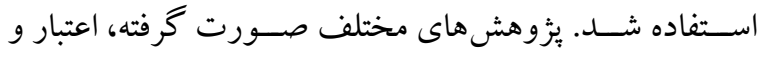

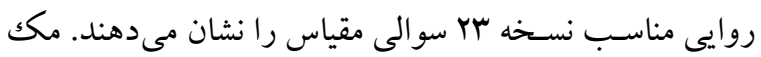

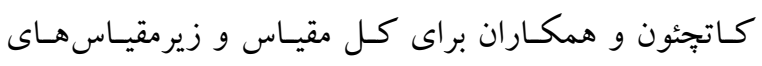
سر گرمى -اجتماعى، اشـياق-شـخصى، و مرزى -بيمار گونه به ونه

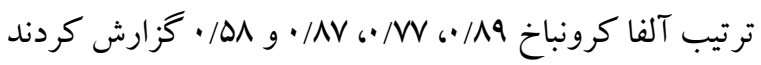
(IV)

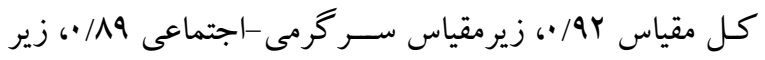
مقياس اشتياق-شخصى /^/، · و زيرمقياس مرزى-بيمار كونه

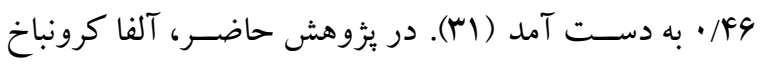
بر اى كل مقياس و زيرمقياس هاى سر گرمى -اجتماعى، اشتياق-

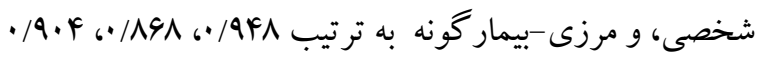
و NDQ · به دســت آمد كه حاكى از همســانى درونى مقياس

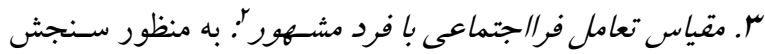

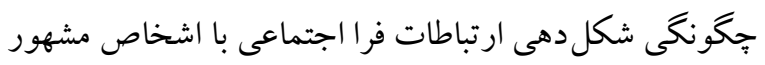

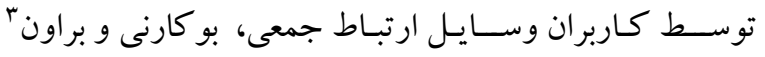
مقياس تعامل فرا اجتماعى با فرد مشهور را طراحى كردند. اين

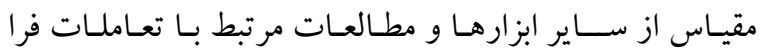

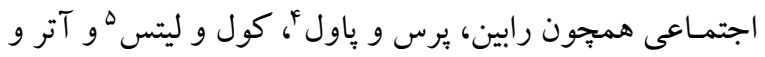

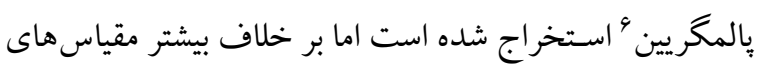

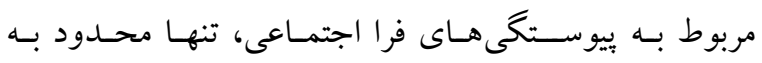
شـخصـيت هاى تلويزيونى نيسـت. درحالى كه بيشـتر ابزارهاى

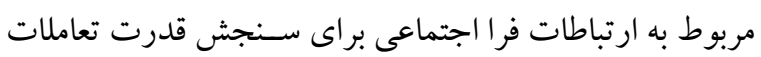

1. Borderline-personal

2. Celebrity parasocial interaction scale

3. Bocarnea \& Brown

4. Robin, Perse \& Powell 
دانش آموزان اين امكان داده شــــ كه در هر لحظه از يزوهش در جدول ا شاخص هاى توصيفى مربوط به متغير هاى بثزوهش

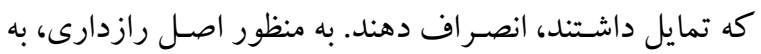

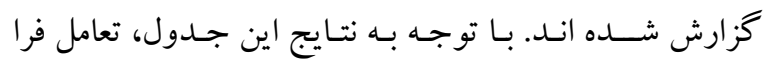

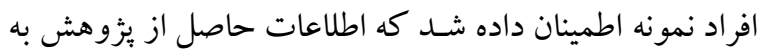

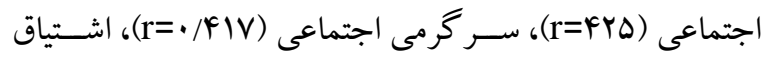
صـورت گروهى مورد تحليـل قرار خواهد گرفت و اطلاعات

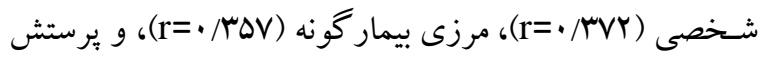

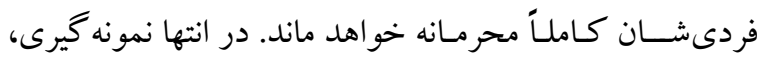
افراد مشـهور (r=/A|N) با تحريفات شـناختى بين فردى رابطه توضــيحات شــفاهى كاملترى در مورد موضــوع، روش، و مثبت معنى دارى در سطح 1 • / دارند.

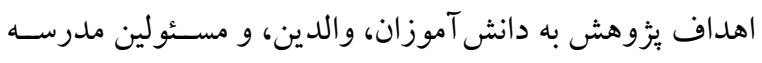

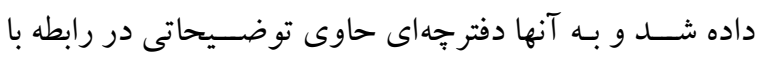
يرستش افراد مشهور و بيامدهاى آن اهدا شد.

جدول ا: ماتريس همبتغى متغيرهاى برووهش

\begin{tabular}{|c|c|c|c|c|c|c|c|c|c|c|c|c|}
\hline 9 & 1 & $\bar{Y}$ & 7 & 0 & $\varepsilon$ & $r$ & $r$ & 1 & SD & ميانكين & متغير & \\
\hline & & & & & & & & 1 & $r F / V A$ & $\Delta N / Y V$ & تعامل فرا اجتماعى & 1 \\
\hline & & & & & & & 1 & $\cdot / \mathrm{A} \cdot{ }^{* * *}$ & N/Dr & $r r / \Lambda I$ & سر گرمى اجتماعى & r \\
\hline & & & & & & 1 & $\cdot / V V r^{* * *}$ & $\cdot / V Y I^{*: B}$ & $1 . / 11$ & $r \mu / F \Delta$ & اشتياق شخصى & $r$ \\
\hline & & & & & 1 & $\cdot / N \cdot r^{* * *}$ & $.1994^{* * * *}$ & $\cdot / 9 M K^{* 3 *}$ & $\varphi /$. & N/FG & مرزى بيمار گونه & f \\
\hline & & & & 1 & $\cdot / \wedge \cdot 9^{* *}$ & $\cdot / q 4 \cdot * *$ & $\cdot / a Y Y^{B *}$ & $\cdot / \mathrm{N} \mid \mathrm{f}^{* * s}$ & Yr/AV & $91 / 91$ & يُرستش افراد مشهور (كل) & $\Delta$ \\
\hline & & & 1 & $\cdot / r \mid 9^{* * * *}$ &.$/ 19 \Delta^{* * * *}$ & $\cdot / r Y V^{* * * *}$ & 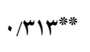 & $\cdot /\left.Y \wedge\right|^{* * * *}$ & $\Delta / 1$ & $r r / \Lambda q$ & طرد در روابط & 4 \\
\hline & & 1 & $\cdot / r \Lambda r^{* * * *}$ & $\cdot / r \Delta r^{* * * *}$ & $\cdot / r Y \Lambda^{* * * *}$ & $\cdot / \times 9 \Delta^{* * * *}$ & $\cdot / r 9 \Lambda^{* * * *}$ & $\cdot / r q V^{* * * * *}$ & $\Delta / r r$ & $r F / T V$ & انتظارات غيرواقع بيبانه & $v$ \\
\hline & 1 & $\cdot / \Upsilon \wedge 9^{* * * *}$ & $\cdot / r \cdot \varphi^{* * * *}$ & $\cdot / \Lambda \Delta \Lambda^{* * * *}$ & $. / 9 \mathrm{~V})^{* * * *}$ & $\cdot / \Lambda V^{* * * * *}$ & $\cdot /$ VQ.**** & $\cdot / 99 \cdot * * * *$ & $r / 91$ & $\mathrm{~V} / \mathrm{TV}$ & سوء ادراكs & $\wedge$ \\
\hline 1 & $\cdot / \Gamma \Delta q^{* * * *}$ & $\cdot /\left.A r\right|^{* * *}$ & ·/var"*:* & $\cdot / \kappa \mid \Lambda^{* * * *}$ & $\cdot / r \Delta V^{* * * *}$ & $\cdot / \Upsilon \wedge r^{* * * * *}$ & $\cdot / \kappa \mid V^{* * * *}$ & $\cdot / \kappa r \Delta^{* * * *}$ & $9 / 9 \mathrm{~V}$ & $\Delta 91.4$ & تحريفات شناختى بين فردى (كل) & 9 \\
\hline
\end{tabular}

سـوم اشـتياق شـحصى، در گام جهارم مرزى بيمار گونه، و در

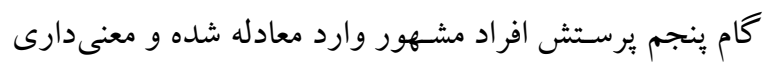
خود را طى هنج كام حفظ كردند. در جدول r نتايج تحليل رگرسيون گزارش شده است.
براى بيش بينى تحريفات شــاختى بين فردى نوجوانان از

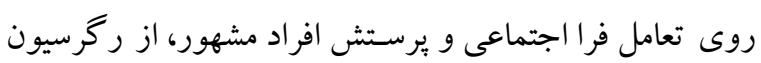
جند گانه به صورت كام به كام استفاده شد كه در گام اول متغير تعامل فرا اجتماعى، در گام دوم ســر گرمى اجتماعى، در گام

جدول ז: خلاصه مدل ركر سيون، تحليل واريانس و مشخصههاى آمارى ركرسيون تحريفات شناختى بينفردى بر متغيرهاى بيشيين

\begin{tabular}{|c|c|c|c|c|c|c|c|c|c|}
\hline $\mathbf{A} \mathbf{R}^{2}$ & $\mathbf{R}^{2}$ & $\mathbf{R}$ & $\mathbf{P}$ & F & ميانكين مجمورات & df & مجذمورع & شاخصها & كام \\
\hline \multirow{2}{*}{./IVV } & \multirow{2}{*}{.$/ 1$} & \multirow{2}{*}{$\cdot / 4 r$} & \multirow{2}{*}{$\cdot / . .1$} & \multirow{2}{*}{$F r / 90$} & $r+9 V / I 1$ & 1 & $r \mu q V / 11$ & ركرسيون & \multirow{2}{*}{1} \\
\hline & & & & & $\mathrm{V} / \mathrm{N}$ & 191 & 1OTVY/19 & باقيمانده & \\
\hline \multirow{2}{*}{ •/119 } & \multirow{2}{*}{$\cdot / 19$} & \multirow{2}{*}{$\cdot / F 4$} & \multirow{2}{*}{$\% \cdot .1$} & \multirow{2}{*}{$r F / M \Lambda$} & $\| A r V / \cdot A$ & r & revr/fe & ركرسيون & \multirow{2}{*}{ r } \\
\hline & & & & & VD/99 & $19 \mathrm{~V}$ & $19990 / 11$ & باقيمانده & \\
\hline \multirow{2}{*}{. /M } & \multirow{2}{*}{$/ r$} & \multirow{2}{*}{$\cdot / F F$} & \multirow{2}{*}{ 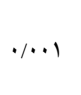 } & \multirow{2}{*}{$19 \pi / \Delta$} & IrFf/Tr & $r$ & $r v r / r q q$ & ركرسيون & \multirow[t]{2}{*}{$r$} \\
\hline & & & & & $v 91.0$ & 199 & $1 F 9.9 / M$ & باقيمانده & \\
\hline \multirow{2}{*}{ •/AV } & \multirow{2}{*}{$\cdot / r 1$} & \multirow{2}{*}{.$/ \% \Delta$} & \multirow{2}{*}{ 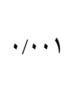 } & \multirow{2}{*}{$1 r / 49$} & $9 F / / A 9$ & F & $r V q \Delta / \Delta V$ & ركرسيون & \multirow{2}{*}{ F } \\
\hline & & & & & V9/1r & 190 & $|F A F T M|$ & باقيمانده & \\
\hline \multirow{2}{*}{$\cdot / r Y}$. & \multirow{2}{*}{$\cdot / M F$} & \multirow{2}{*}{.$/ 49$} & \multirow{2}{*}{$\% \cdot .1$} & \multirow{2}{*}{$r \pi / r}$. & $\wedge 91 / \mathrm{VV}$ & $\Delta$ & $\mu F \Delta / / \wedge \Delta$ & ركرسيون & \multirow{2}{*}{$\Delta$} \\
\hline & & & & & $v r / .9$ & lap & $|F| \Lambda \cdot k T$ & باقيمانده & \\
\hline
\end{tabular}




\section{كام זّ متغير بيشبين: تعامل فرا اجتماعى، سر گرمى اجتماعى، اشتياق شخصى

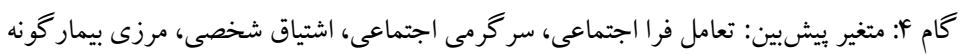

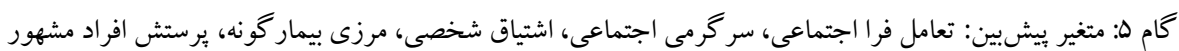

يرستش افراد مشـهور YF درصد از تغييرات تحريفات شناختى بين فردى را ييشبينى مى كنند. ميزان F مشــاهده شـــده براى

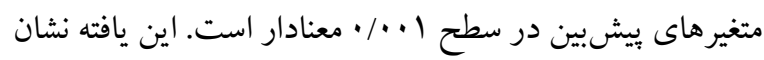

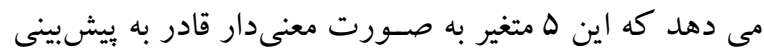
تحريفات شـناختى بين فردى هسـتند. در جدول آ، نيز ضـرايب

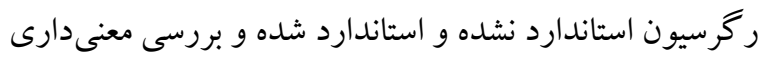

$$
\text { اين ضر ايب كزارش شدهاند. }
$$

براسـاس نتايج مندرج در جدول r، مى توان نتيجه گرفت در تبيين تحريفـات شــــاختى بينفردى از روى متغيرهـاى

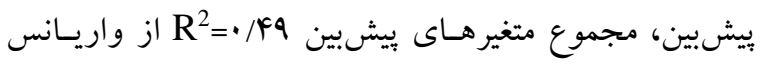

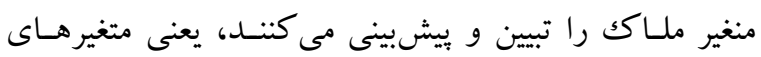
بيشبين لها درصسد نمره تحريفات شـناختى بينفردى را تبيين

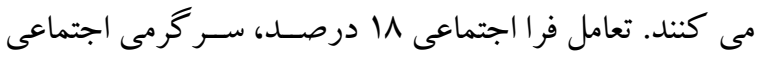

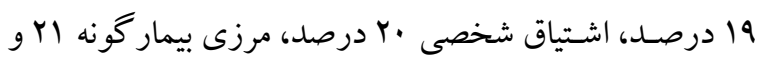

جدول "ا: ضرايب ركر سيون كام به كام تحريفات شناختى يينفردى روى متغير هاى ييشيين

\begin{tabular}{|c|c|c|c|c|c|}
\hline معنادارى & $\mathbf{t}$ & B & خطاى استاندارد b & B & شاخص ها/متغيرها \\
\hline.$/ . .1$ & $Y F / F \mid$ & - & $1 / A 1$ & FF/YY & عرض از مبدا \\
\hline $.1 .1 \mathrm{k}$ & $r / \uparrow \Lambda$ & $\cdot / T V$ &.$/ 4$ & $\cdot /$ & تعامل فرا اجتماعى \\
\hline..$\cdot 1$ & $r / r r$ & ./lr & $\cdot / 4 \lambda$ & $\cdot / \Delta V$ & سر گرمى اجتماعى \\
\hline$\cdot / . r$ & $r / . r$ & $\cdot / / 4$ &.$/ 4 \Delta$ & $\cdot / r \wedge$ & اشتياق شخصى \\
\hline.$\cdot \cdot r$ & $r / 11$ & .190 &.$/ \Delta$ & $\cdot / \Delta V$ & مرزى بيمارگونه \\
\hline...$r$ & $r / .1$ & $\cdot / \mu$ & $\cdot / 41$ & $\cdot / 49$ & يرستش افراد مشهور \\
\hline
\end{tabular}

\section{بحث و نتيجه كيرى}

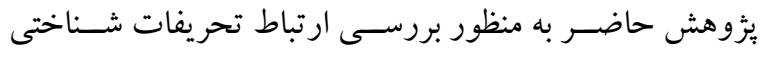
بين فردى، يرستش افراد مشهور، و تعامل فرا اجتماعى با آنها در دانش آموزان يسر و دختر مقاطع هشتم و نهم دوره اول مدارس ترس

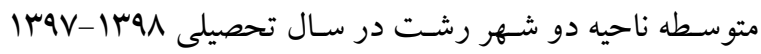
انجام شـد. بر طبق نتايج به دست آمده، برستش افر اد مشهور و و

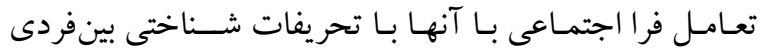

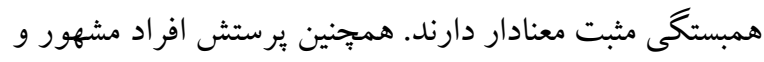

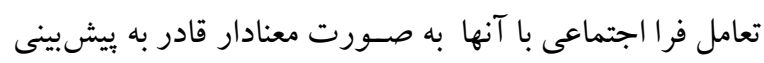
تحريفات شناختى بين فردى هستند كه حاكى از نقش و اهميت

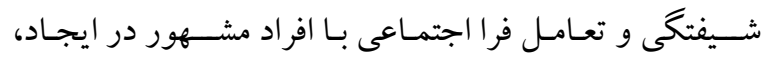
نخهارى، و گسترش تحريفات شناختى بينفردى در نوجو انان
بـا توجـه بـه جـدولها، اثر تعامل فرا اجتماعى بر تحريفات

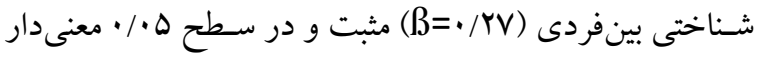
اسـت، اثر سـر گرمى اجتماعى بر تحريفات شـناختى بينفردى

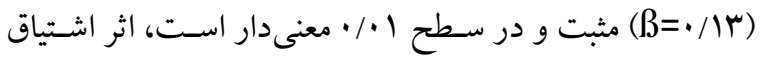

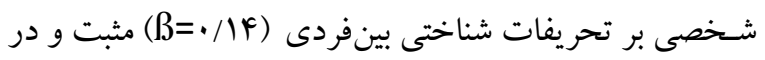

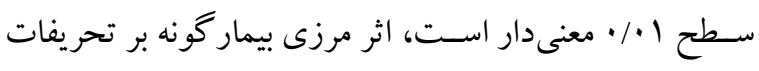

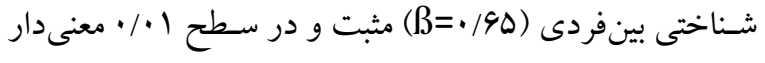
است، و همجنين اثر برستش افراد مشهور بر تحريفات شناختى

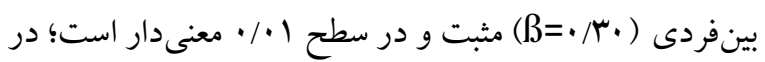

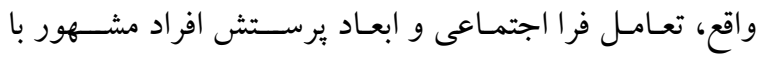
تحريفات شـناختى بين فردى همبستخى مثبت دارند كه نشانگر

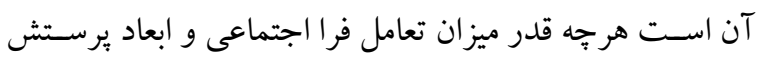
افراد مشــهور در دانش آموزان بـالا بـاشـــ، ميزان تحريفات شناختى بين فردى فرد بالا خو اهد بود و برعكس. 
همجِين تعامل فرا اجتماعى با افراد مشـهور به عنوان ديخر يديده مشـابه با برســتش افراد مشــهور و به معناى ارتباط بين

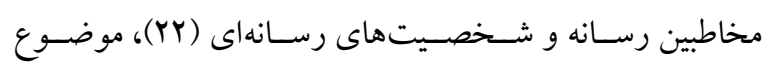

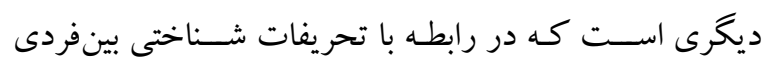
نوجوانان بايد متصسور بود. با در نظر گرفتن مطالعات صسورت

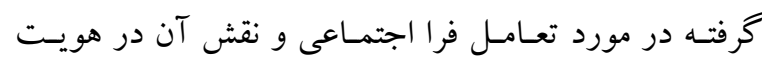

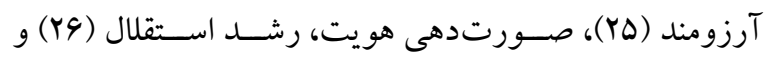

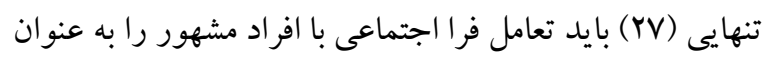
يديدهاى كه مى تواند بر تحريفات شناختى نوجوانان موثر واقع

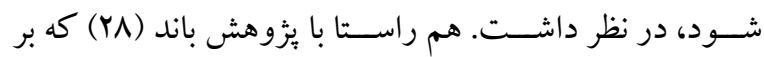
شــباهت ارتباطات فرا اجتماعى و تعاملات دنياى و اقعى تاكيد

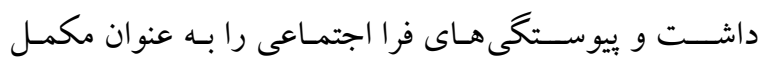

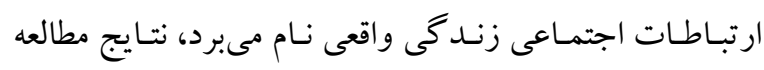

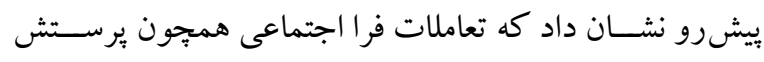

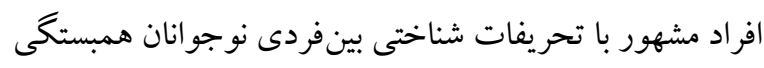

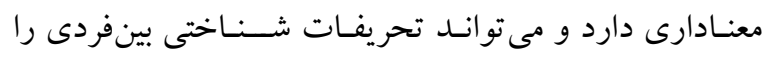

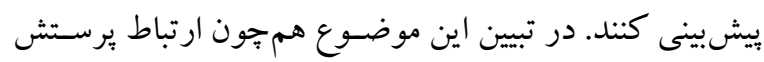

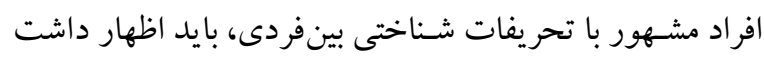

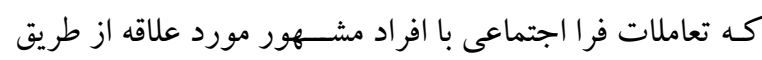

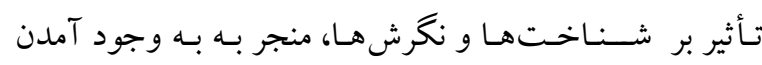
تحريفاتى شناختى در رابطه با ارتباط با ديخران مى شوده بر طبق نتايج يثزوهش حاضر، برستش افراد مشهور و تعامل

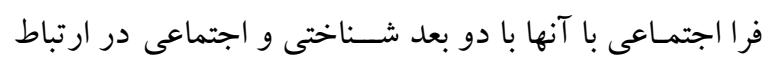

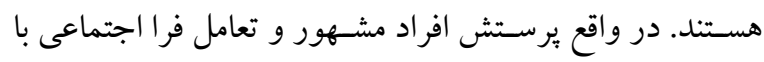

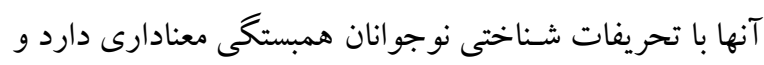

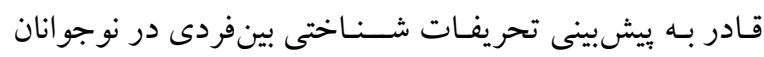

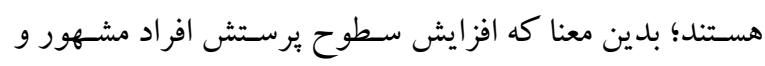

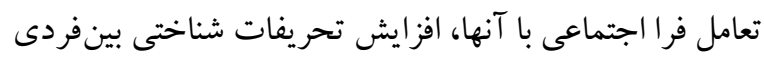

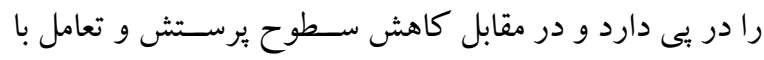

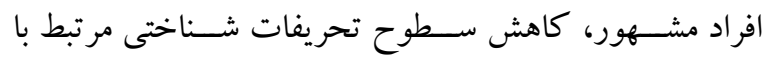

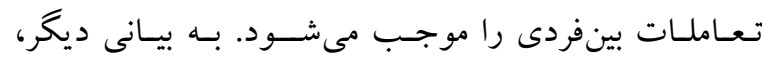

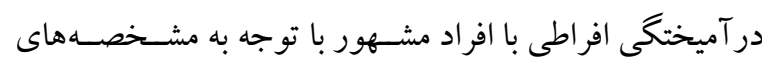

يرســش افراد مشـهور به عنوان شـيفتكى نسـبت به افر اد مشهور و بروز رفتارهاى وسواس گونه (V) با طيف گستردهاى

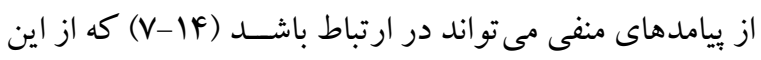
بين تحريفات شـناختى بين فردى مى تواندل از جمله موضو عاتى باشـند كه متأثر از شـيفتكى و يرستش افراد مشهور قرار گيرند.

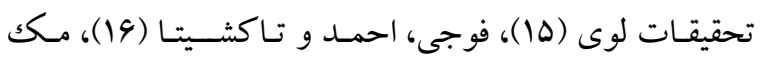

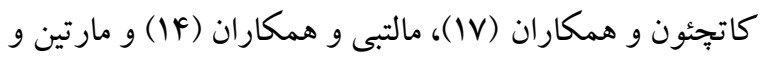

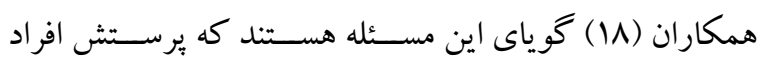

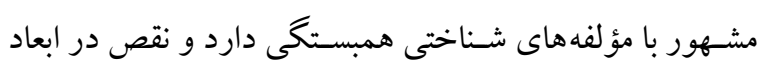

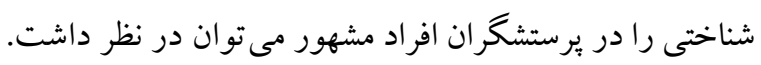

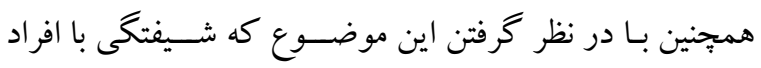

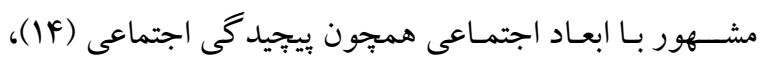

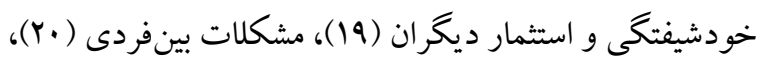
تنهايى و خجالت (YI) ارتباط تنگاتنكى دارد، مى توان اذعان داشت كه برستش افراد مشهور مى تواند عاملى مهمى در ايجاد

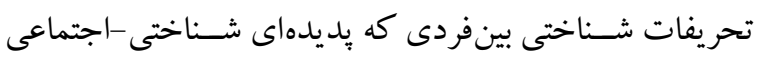

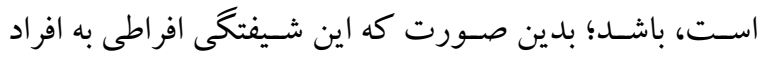

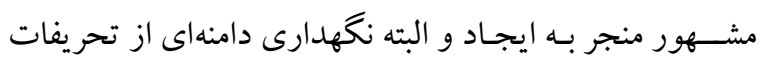

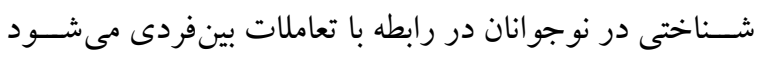
بدين صسورت كه بر كيفيت، مشسخصسها و و اهداف ارتباطات

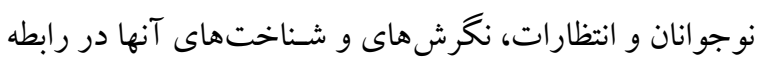

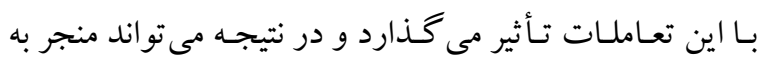
بيامدهاى منفى بسـيارى در ابعاد مختلف گر دد. مطالعه حاضسر

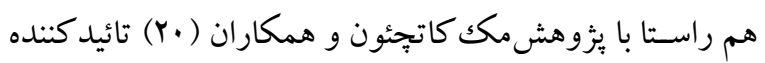
اين موضوع است كه يرستش افراد مشهور و زيرمقياس هاى آن

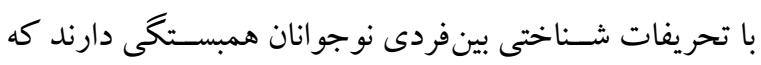

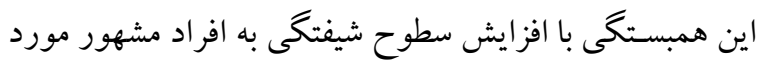

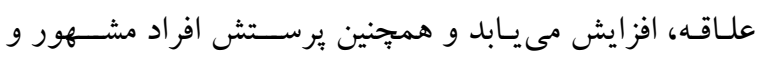

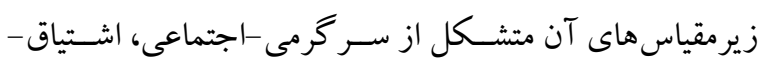

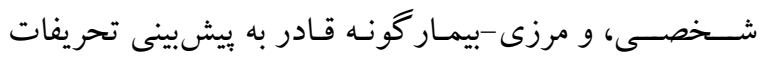
شناختى بين فردى نوجو انان هستند. 


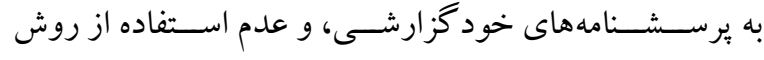
نمونه گيرى تصـادفى از جمله اين محدوديت ها بوده اسـت. در بر برد

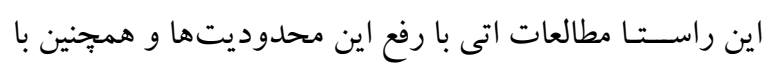

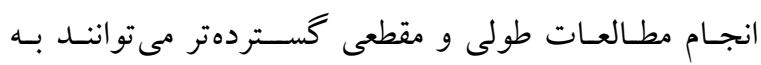
تعميمدهى هرجه بيشتر نتايج به دست آمده كمكك كنند و ما را در دسترسى به يكك مدل ساختارى مناسب يارى كنند.

تشكر و قدردانى: اجراى اين مطالعه به صورت مستقل و با مجوز

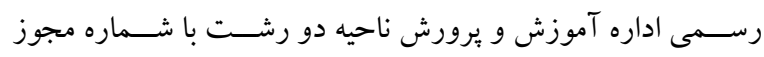
نو

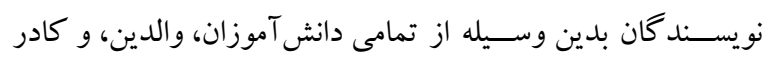

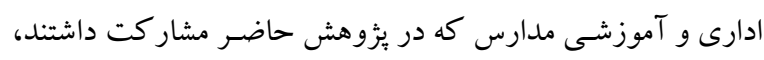
قدردانى مى كنند.

تضاد منافع: اين يُزوهش براى نويسـند كان هيج گُنه تضاد منافعى

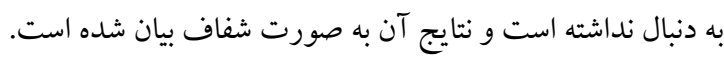

خاص، آرمانى و تا حدودى دسـتنيافنىشـان منجر به ايجاد،

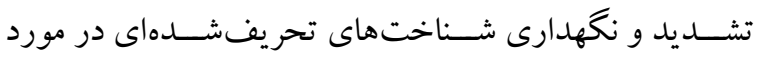

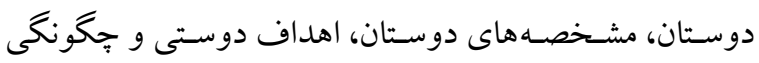

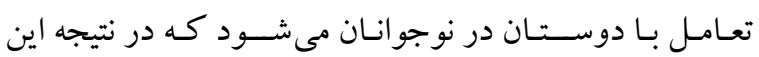
شـناخت هاى تحريفشــه، مشـكلاتى در تعاملات و ارتباطات بين فردى آنان به وجود مى آيد. در نتيجه استفاده از راهبردهايى

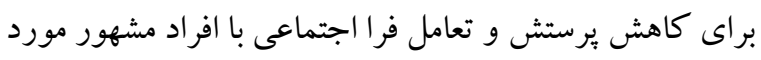
علاقه مى توانند در كاهش سطوح تحريفات شناختى بينفردى

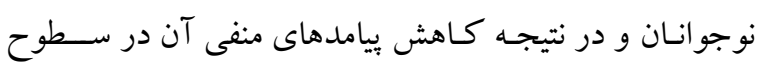

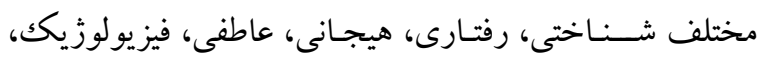
اجتماعى، فرهنكى و حتى اقتصادى، موثر واقع شود.

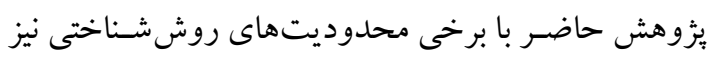
مواجه بوده است. محدود بودن نمونه مورد مطالعه به دامنه سنى

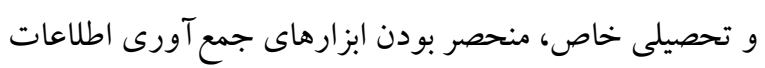




\section{References}

1. Hamamci Z, Büyüköztürk S. The interpersonal cognitive distortions scale: Development and psychometric characteristics. Psychol Rep. 2004; 95(1): 291-303. [Link]

2. Coban AE. Interpersonal cognitive distortions and stress coping strategies of late adolescents. Eurasian Journal of Educational Research. 2013; 51: 65-84. [Link]

3. Giordano PC. Relationships in adolescence. Annu Rev Sociol. 2003; 29: 257-281. [Link]

4. Turner G. Approaching celebrity studies. Celebr Stud. 2010; 1(1): 11-20. [Link]

5. Xiaozhong H. Survey report on idol worship among children and young people. Chinese Education \& Society. 2006; 39(1): 84-103. [Link]

6. Martin MM, McCutcheon LE, Cayanus J. Celebrity worship and its relationship to television-watching motives: A brief report. N Am J Psychol. 2015; 17(2): 213-219. [Link]

7. McCutcheon LE, Lange R, Houran J. Conceptualization and measurement of celebrity worship. Br J Psychol. 2002; 93(1): 67-87. [Link]

8. Aruguetem M, Griffith J, Edman J, Green T, Mccutcheon L. Body image and celebrity worship. Implicit Relig. 2014; 17(2): 223-234. [Link]

9. Ang CS, Chan NN. Adolescents' views on celebrity worship: A qualitative study. Curr Psychol. 2018; 37(1): 139-148. [Link]

10. McCutcheon LE, Aruguete MS, Jenkins W, McCarley N, Yockey R. An Investigation of Demographic Correlates of the Celebrity Attitude Scale. Interpersona, 2013; 10(2): 161-170. [Link]

11. Maltby J, Day L, McCutcheon LE, Gillett R, Houran J, Ashe DD. Personality and coping: A context for examining celebrity worship and mental health. Br J Psychol. 2004; 95(4): 411-428. [Link]

12. Maltby J, McCutcheon LE, Ashe DD, Houran J. The self-reported psychological well-being of celebrity worshippers. N Am J Psychol. 2001; 3(3): 441-452. [Link]

13. Maltby J, McCutcheon LE, Lowinger RJ. Brief report: celebrity worshipers and the five-factor model of personality. N Am J Psychol. 2011; 13(2): 343-348. [Link]

14. Maltby J, Day L, McCutcheon LE, Martin MM, Cayanus JL. Celebrity worship, cognitive flexibility, and social complexity. Pers Individ Dif. 2004; 37(7): 1475-1482. [Link]

15. Levy MR. Watching TV news as para-social interaction. Journal of Broadcasting. 1979; 23(1): 69-80. [Link]

16. Fujii DEM, Ahmed I, Takeshita J. Neuropsychologic implications in erotomania: two case studies. Neuropsychiatry Neuropsychol Behav Neurol. 1999; 12(2): 110-116. [Link]

17. McCutcheon LE, Ashe DD, Houran J, Maltby J. A Cognitive profile of individuals who tend to worship celebrities. The Journal of Psychology Interdisciplinary and Applied. 2003; 137(4): 309-322. [Link]

18. Martin MM, Cayanus JL, McCutcheon LE, Maltby J. Celebrity worship and cognitive flexibility. N Am J Psychol. 2003; 5(1): 75-80. [Link]

19. Ashe DD, Maltby J, McCutcheon LE. Are celebrity-worshippers more prone to narcissism? A brief report. N Am J Psychol. 2005; 7(2): 239-246. [Link]

20. McCutcheon LE, Gillen MM, Browne BL, Murtagh MP, Collisson B. Intimate relationships and attitudes toward celebrities. Interpers Int J Pers Relatsh. 2016; 10(1): 77-89. [Link]

21. Ashe DD, McCutcheon LE. Shyness, loneliness, and attitude toward celebrities. Current Research in Social Psychology. 2001; 6(9): 124-132. [Link]

22. Giles DC. Parasocial Interaction: A review of the literature and a model for future research. Media Psychol. 2002; 4(3): 279-305. [Link]

23. Dibble JL, Hartmann T, Rosaen SF. Parasocial interaction and parasocial relationship: conceptual clarification and a critical assessment of measures. Hum Commun Res. 2016; 42(1): 21-44. [Link]

24. Horton D, Wohl RR. Mass communication and para-social interaction. Psychiatry. 1956; 19(3), 215 229. [Link]

25. Hoffner C. Children's wishful identification and parasocial interaction with favorite television characters. J Broadcast Electron Media. 1996; 40(3): 389-402. [Link] 
26. Gleason TR, Theran SA, Newberg EM. Parasocial interactions and relationships in early adolescence. Front Psychol. 2017; 8: 255. [Link]

27. Wang Q, Fink EL, Cai DA. Loneliness, gender, and parasocial interaction: A uses and gratifications approach. Commun Q. 2008; 56(1), 87-109. [Link]

28. Bond BJ. Parasocial relationships with media personae: Why they matter and how they differ among heterosexual, lesbian, gay, and bisexual adolescents. Media Psychol. 2018; 21(3): 457-485. [Link]

29. EsmaeelPoor K, BakhshiPoor Rodsari A, Mohammadzadegan R. Determining factor structure, validity and reliability of interpersonal cognitive distortions scale among students of Tabriz University. Cognitive Strategies in Learning. 2015; 2(3): 53-72. [Persian]. [Link]

30. Sansone RA, Sansone LA. "I'm your number one fan"- a clinical look at celebrity worship. Innov Clin Neurosci. 2014; 11(1-2): 39-43. [Link]

31. Reeves RA, Baker GA, Truluck CS. Celebrity worship, materialism, compulsive buying, and the empty self. Psychol Mark. 2012; 29(9): 674-679. [Link]

32. Bocarnea MC, Brown WJ. Celebrity-persona parasocial interaction scale. In: Reynolds RA, Woods R, Baker JD, editor. Handbook of research on electronic surveys and measurements. Hershey, PA, US: Idea Group Reference/IGI Global; 2007, pp: 309-312. [Link] 